\title{
A Foot in the Past: Existing Literature
}

Scholars studying European competition law have focused both on its philosophical background and on its evolution. ${ }^{12}$ These works have dealt with the substantive and procedural aspects of EU competition law in parallel, with little overall attention paid to due process. ${ }^{3}$ More recent monographs adopted a different approach by placing due process at the centre of their discussions of European competition law. 4

The study of fundamental rights in Europe has also been divided into two separate clusters as well: the first, following the development of human rights by the ECtHR in Strasbourg; the second, focusing on the work of the EU institutions, including the CJEU. ${ }^{5}$ At the same time, scholars have always had a soft spot for topics that cover the dialogue between the two courts and the two legal systems. ${ }^{85}$

A recent trend in legal doctrine has been to bridge the gaps between different fields of law. It is in this context that "and human rights" writings have developed. Business and human rights, investment law and human rights and WTO law and human rights are fields of study that have created intimacies between areas of law which previously remained separated, and that have highlighted a generalized readiness to engage with the field of human rights. ${ }^{6}$

1 Amato, Giuliano. Antitrust and the Bounds of Power: The Dilemma of Liberal Democracy in the History of the Market. Oxford: Hart Publishing, 1997.

2 Bellamy, C., and G. Child. Common Market Law of Competition. London: Sweet and Maxwell, 1987.

Amato, Giuliano, and C. Ehlermann, eds. EC Competition Law: A Critical Assessment. Oxford: Hart Publishing, 2007.

Townley, C. Article 81 EC and Public Policy. Oxford: Hart Publishing, 2009.

Ezrachi, A. Article 82: Reflections on its Recent Evolution. Oxford: Hart Publishing, 2009.

3 Vogel, L. European Competition Law. Bruxelles: Bruylant, 2015.

4 Van Bael, Ivo. Due Process in European Competition Proceedings. Bruxelles: Kluwer Law International, 2011.

5 Grabenwarter, C. op. cit.

Harris, D., M. O'Boyle, Ed Bates and C.M. Buckley. op. cit.

Keller, H., and A. Stone Sweet, eds. op. cit.

6 Cottier, Thomas. "Trade and Human Rights: A Relationship to Discover." Journal of International Economic Law 5.1 (2002): pp. 111-132.

Cottier, Thomas, Joost Pauwelyn and Elisabeth Bürgi, eds. Human Rights and International Trade. Oxford: Oxford University Press, 2005.

Bird, Robert C., Daniel R. Cahoy, Jamie Darin Prenkert, eds. Law, Business and Human Rights: Bridging the Gap. Cheltenham: Edward Elgar, 2014. 
In this context, the increased intimacy between competition law and human rights law was inevitable. The perfect locus for creating this intimacy is the notion of procedural fairness, a tested human rights concept that challenged some of the ingrained procedural aspects of competition law. A few events have accelerated interest in the two fields.

First, a few cases such as Microsoft $v$ Commision have spurred a new interest in the subject of procedural fairness due to the fines imposed by the Commission and the procedural issues raised. ${ }^{7}$ Second, the accession of the European Union to the ECHR pushed the debate on procedural fairness in competition law to a new level.

The following sections provides a description of the discussions in the academic literature that are relevant to this book.

\subsection{Legal Philosophy}

The discourse on due process and fair trail is closely related to the discourse on the meaning of judicial review, which is then closely related to the discourse on law and the meaning of interpreting the law. It is therefore impossible to avoid a short incursion into legal philosophy which has provided very fertile soil for debating these issues.

Starting with Bentham, process and procedure, and the notion of fairness that accompanies them, constituted a core element of realizing the principles of morals and legislation. For Bentham, the process appears to be a corollary of the idea that judges are making the law; they do not simply discover it as defended by the natural law proponents. ${ }^{8}$

Modern philosophers, such as Ely and Dworkin, have written extensively about the meaning of law and the social basis for procedural justice. Both American scholars have widely argued in favour of judicial activism and against judicial restraint. Dworkin introduced the distinction between concepts and conceptions, arguing that constitutional texts contain concepts that are best revealed as conceptions through judicial review. ${ }^{9}$

In his seminal work, Democracy and Distrust: A Theory of Judicial Review, Ely proposed an interpretivist theory of judicial review that should distance itself

Baumann-Pauly, Dorothée and Justine Nolan, eds. Business and Human Rights: From Principles to Practice. New York: Routledge, 2016.

7 T-167/o8, Microsoft v Commission, ECLI:EU:T:2012:323.

8 Bentham, Jeremy. The Principles of Morals and Legislation. New York: Methuen, 1982.

9 Dworkin, R. Taking Rights Seriously. Cambridge: Harvard University Press, 1977. 
from dealing with the constitutional provisions as separate, self-contained units and embrace a judicial review committed to the interpretation of each provision in light of the constitution as a whole document. ${ }^{10} \mathrm{He}$ then offered three reasons for a "participation-oriented, representation-reinforcing approach to judicial review".11 The first is that examination of the nature of the US Constitution finds it to provide a guarantee of process, not a description of substantive values. The second is that judges should "confine themselves to policing the mechanisms by which the system seeks to ensure that (...) elected representatives will actually represent". ${ }^{2}$ Lastly, noting that "the ins are choking off channels of political change" and that a majority is "systematically disadvantaging some minority" out of simple hostility or prejudice, Ely argues that judges, as "comparative outsiders", are in an objective position to assess claims that the system is malfunctioning. In other words, judges should assess whether the process is worthy of trust. ${ }^{13}$

More recently, Galligan provided a compelling analysis of the concept of procedural justice when applied to the field of administrative law. ${ }^{14}$ For Galligan, procedural justice is an essential element for the attainment of law and the goals of politics, "for no matter how good and just the laws and political principles supporting them may be, without suitable procedures they would fail in their purposes". ${ }^{15}$ Procedures on the one hand are deeply rooted in the social context that has created them, and on the other hand reflect the beliefs prevailing in the society that has created them.

Galligan proposes three constitutive elements to the notion of procedural justice:

First, legal procedures are fair procedures to the extent that they lead to or constitute fair treatment of the person or persons affected. Second, within each type of legal process, there are authoritative standards based on the tiers of values relevant to that process which constitute the standards of fair treatment, so that a person treated in accordance with them is treated fairly. Thirdly, the basis of such treatment being fair treatment

\footnotetext{
10 Dworkin, op. cit., pp. 12-14 and 41.

1 Ely, John Hart. Democracy and Distrust: A Theory of Judicial Review. Cambridge: Harvard University Press, 1980, p. 87.

12 Ely, op. cit., p. 100-101.

13 Ely, op. cit., p. 102-103.

14 Galligan, D. J. Due Process and Fair Procedures: A Study of Administrative Procedures. Oxford: Oxford University Press, 1996.

15 Galligan, op. cit., p. 9.
} 
is the promise of society as a whole to each of its members that they will be treated in that way. ${ }^{16}$

He argues that the normative expectations of citizens in the field of procedural fairness both include and go beyond written legal principles.

Turning to the issue of procedural justice in administrative proceedings, Galligan suggests that in the administrative context, "the inadequacy of procedures is less dramatic but more pervasive". ${ }^{17}$ He shows that the decisions of agencies, officials, and tribunals are seriously unreliable, with almost as much chance of being wrong as being right. To avoid moral harm "every effort should be made to devise the best procedures possible within the resources available". 18

Somewhat reminiscent of Ely, Galligan proposes that participation - even if not automatically required in all legal and administrative processes - possesses a few virtues which allow it to prevent or lessen the moral harm that results from administrative processes. First, participation is a necessary instrument to seek for and reach fair outcomes. Second, administrative processes often fall between legal and political processes and incorporate elements of both. Participation can clarify these distinctions. A third reason why participation appears to be closely linked to procedural fairness

derives from the idea that it enables a person to exert influence over the processes by which he or she is affected. This idea taps a deep spring in modern political theory: it conveys the idea that persons ought to be in charge of their lives and future, and that being involved in any process affecting them is one way of doing so. ${ }^{19}$

\subsection{A Renewed Debate on Human Rights}

To say that the founders of the Strasbourg system of human rights protection were visionaries is to pronounce the truth. When Teitgen proposed the creation of an international Court, he meant "to create a conscience in Europe

\footnotetext{
16 Galligan, op. cit., p. $5^{2}$.

17 Galligan, op. cit., p. 116.

18 Galligan, op. cit.

19 Galligan, op. cit., p. 129.
} 
which will sound the alarm" and that it would be "a Court belonging to Europe itself". 20

Also, as Bates wrote, the entry into force of the European Convention of Human Rights represented "a quantum leap in international law", because

for the first time a treaty was in place by which sovereign States promised to secure to everyone within their jurisdiction a number of rights and freedoms. Each ratifying State would be under an international legal obligation to amend that law if necessary. For such reasons the Convention was revolutionary for its time, and the more so as the advances just mentioned were reinforced by the principle of collective enforcement. ${ }^{21}$

Despite the importance of the entry into force of the ECHR, the initial reactions of the legal profession and the press were weak. Bates quotes the works of Cedric Thornberry, a British barrister who has represented many applicants at the ECtHR, criticizing the fact that the leading law schools in the United Kingdom have either dismissed the idea of offering human rights course on the grounds that human rights has nothing to do with law, or have treated human rights as some sort of exotic field of study. ${ }^{22}$

Interest in human rights and in the Strasbourg system of human rights protection has increased over time, somewhat proportionally to the number of decisions adopted by the Court. However, and in spite of the growing number of judgments delivered by the ECtHR, human rights law has traditionally been studied by only a small number of scholars.

Freeman noted that the study and the practice of human rights have been dominated by lawyers and that the human rights movement owed a great debt to them. He stressed that "there is a danger, however, that excessive attention to human rights law distorts our understanding of human rights". ${ }^{23} \mathrm{He}$ proposes human rights as a concept that can help with understanding and organizing information about the world around us. ${ }^{24}$ For him, human rights is an

20 Teitgen, P.H. "The European Guarantee of Human Rights: A Political Assessment." Proceedings of the Fourth International Colloqui about the European Convention on Human Rights, held in Rome in 1975. Ed. Council of Europe. Strasbourg: Council of Europe, 1976, p. 29 .

21 Bates, Ed. The Evolution of the European Convention on Human Rights. Oxford: Oxford University Press, 2010, p. 108.

22 Bates, op. cit., pp. 13-15.

23 Freeman, Michael. Human Rights: An Interdisciplinary Approach. Cambridge: Polity Press, 2011, p. 13 .

24 Freeman, op. cit., p. 3. 
interdisciplinary concept that can be comprehensively tackled only within an interdisciplinary framework. Freeman highlights the contributions which recent studies in sociology, anthropology, social psychology and economy have made to the human rights debate and concludes that "there are then signs that the social science of human rights is beginning to wake up". 25

The writings of Freeman signal an important development in the field of study of human rights, specifically that human rights have become increasingly interdisciplinary, blending law with other social sciences.

Political scientists have contributed greatly to the human rights discourse in recent years, adding novel perspectives of analysis. Brysk and JimenezBacardi propose that the globalisation of law is a process that "refers to a linked ensemble of changes in the scale, scope, mode, and juridical forms" and which includes: (1) the global diffusion of legal norms and processes; (2) multilayered pluralism including regional, indigenous and family law; (3) new global legal institutions like the International Criminal Court; (4) transnational law governing private cross-border activities; (5) new repertories of jurisprudence and practice, such as participation rights for noncitizens and (6) the growing salience of conventional interstate and comparative jurisprudence for domestic practice, such as universal jurisdiction for crimes against humanity. ${ }^{26}$ They conclude that the globalization of law has shifted the focus of the human rights debate from the inter-state perspective towards state-society relations.

Other political scientists have concerned themselves with the impact of the human rights instruments. Sandholtz has shown that, on the one hand, the effects of treaties on human rights performance partly depend on how domestic legal institutions integrate with international law and, on the other hand, that human rights law is more effective when it creates a continuum between the national and international legal levels. ${ }^{27}$

Novel actors are identified within this renewed debate on human rights. Gaillet has shown that, starting with the 19th century, the individual person has been considered a secondary actor in the life of the state and a limit to the exercise of public power. At no point was the citizen seen as the foundation of legitimate power. She highlights that the political limits mitigating the recognition of the citizen have been enhanced by the legal limits created to prevent

25 Freeman, op. cit., p. 10.

26 Brysk, A., and A. Jimenez-Bacardi. "The Politics of the Globalization of Law." The Politics of the Globalization of Law: Getting from Rights to Justice. Ed. Alison Brysk. New York: Routledge, 2013, p. 8.

27 Sandholtz, W. "Treaties, Constitutions and Courts." The Politics of the Globalization of Law: Getting from Rights to Justice. Ed. Alison Brysk. New York: Routledge, 2013, p. 29. 
the individual person from having standing in legal disputes. ${ }^{28}$ Gaillet then traces the entry into politics of the German nation and argues that the recognition of what we now call "fundamental rights" has also altered the nature of the relationship between the individual and the exercise of public power. ${ }^{29}$ She concludes that the recognition of fundamental rights and the legal standing to defend them constitute the main channel for subordinating the state administration to the law..$^{30}$

Other scholars also suggest that human rights law has contributed to the rise of the individual as an actor in international law. Focusing on the work of the ECtHR, Cichowski argues that widened access to international judicial organizations can increase the monitoring and enforcement of laws by individuals and by interest and advocacy groups both at the national and international levels. ${ }^{31}$ She notes that "this gives courts a greater opportunity to engage in important political issues through the strategy of incremental development doctrine. Private parties, rather than states, may be more likely to utilize these courts for strategic policy reform". ${ }^{32}$ (emphasis added)

\subsection{A Renewed Imagining of the Trial}

Hirschl started his paper on new constitutionalism by arguing that the world has witnessed "a profound transfer of power from representative institutions to judiciaries, whether domestic or supranational". ${ }^{33}$ The growing power and importance of the judiciary has been studied from various angles. ${ }^{34} \mathrm{Hirschl}$, in an earlier work, proposed that whereas the constitutionalisation of rights may promote procedural justice, it does little for advancing progressive notions of distributive justice. Hirschl calls this phenomenon juristocracy and shows that

28 Gaillet, Aurore. L'individu contre l'Etat: Essaie sur l'évolution des recours de droit public dans l'Allemagne du XIXe siècle. Paris: Dalloz, 2012, p. 166.

29 Gaillet, op. cit., p. 170.

$30 \quad$ Gaillet, op. cit., p. 462.

31 Cichowski, Rachel. "Courts, Advocacy Groups, and Human Rights in Europe." The Politics of the Globalization of Law: Getting from Rights to Justice. Ed. Alison Brysk. New York: Routledge, 2013, p. 108.

32 Cichowski, op. cit., p. 109.

33 Hirschl, Ran. "The New Constitutionalism and the Judicialization of Pure Politics Worldwide." Fordham Law Review 75.2 (2006), p. 721.

34 Shapiro, M., and A. Stone Sweet. On Law, Politics, and Judicialization. Oxford: Oxford University Press, 2002. Ferejohn, J. "Judicializing Politics, Politicizing Law." Law and Contemporary Problems 65.3 (2002): pp. 41-68. 
this trend is part of a broader process whereby proponents of powerful social and economic interests profess support for democracy by attempting to insulate policy-making from the vicissitudes of democratic politics. ${ }^{35}$

In the same vein, Tate and Vallinder argued that the global expansion of the judicial power is accompanied by negotiation and decision-making using quasi-judicial procedures. ${ }^{36}$

New constitutionalism generated a heated debate around justice and the future of the trial. Allan, in his seminal work on constitutional justice, proposed that the rule of law and the separation of powers underlie the trial. ${ }^{37}$ Due process plays a central role in his understanding of the trial and he argues in favour of a more robust definition of due process that can impose tangible limits on the power of government officials. In this conception, due process is a watchdog against partial political processes. ${ }^{38}$

Other scholars are committed to identifying new rules that can guide the trial in a world facing new challenges. ${ }^{39}$ Guinchard proposes that three principles can be developed to answer them and the new expectations of the citizens: (1) the principle of loyalty, with its many implications for professional ethics; (2) the principle of dialogue, including the dialogue between jurisdictions and (3) the principle of speediness. ${ }^{40}$

\subsection{Competition Policy}

A few authors have captured the fate of competition policy in the EU with incredible acuity. Their works continue to inspire generations of curious lawyers and economists.

Amato proposed that the dilemma of liberal democracy is the dilemma of antitrust itself: "The first sets the boundary of public power as far ahead as

35 Hirschl, Ran. Towards Juristocracy: The Origins and Consequences of the New Constitutionalism. Cambridge: Harvard University Press, 2004.

36 Tate, C. N., and T. Vallinder, eds. The Global Expansion ofJudicial Power. New York: New York University Press, 1995 .

37 Allan, T.R.S. Constitutional Justice: A Liberal Theory of the Rule of Law. Oxford: Oxford University Press, 2001.

38 Allan, op. cit., p. 161.

39 Flauss, J.-F. "Les nouvelles frontières du procès équitable." Les nouveaux développments du procès équitable au sens de la Convention européenne des droits de l'homme. Bruxelles: Bruylant, 1996, p. 81.

40 Guinchard, Serge. "Quels principes directeurs pour le procès de demain?" Mélanges Jacques Van Compernolle. Bruxelles: Bruylant, 2004. 
possible, accepting the risk of private power; the second does not accept that risk and instead runs the risk of preventive intrusions by public order". ${ }^{41}$ For Amato, the defining feature of European antitrust - a feature lacking to its American counterpart - is the attitude towards private power. Europeans were historically and culturally accustomed to private power and this explains why European antitrust is based on limiting private economic power, rather than negating it, as in the American example.

The more tolerant attitude of Europeans towards private economic power sheds new light on three defining features of European antitrust: (1) the coexistence of the classical, "surgical" nature of European antitrust with its regulatory nature; (2) the sensitivity of antitrust law to policies such as industrial, regional and social policies; and (3) the objective of market integration, which rigidified the case-law. ${ }^{42}$

Amato called for the "liberation of antitrust law from the multiple purposes it has served in the past", for the weakening of the regulatory propensity and for the creation of an independent European competition authority that would separate (political) regulatory powers from decision-making powers. ${ }^{43}$

Karagiannis suggested that there are four theoretical lenses concerning the origin of European competition policy ${ }^{44}$ First, liberal intergovernmentalism argues that European competition law has been "born out of German or French government's persistence in representing those organised interests which wished to see a policy institutionalised at the European level".45

Second, the hegemonic theory argued that competition policy was adopted because "(1) anti-trust was popular in the United States; and (2) post-World War II Europe was created in America's own image as projected by American policy makers". 46

Third, the political transaction costs theory suggests that "parties that contemplate an otherwise efficient voluntary transaction may actually forego to transact by fear of being held-up". ${ }^{4}$

Gerber starts his seminal work on law and competition with a metaphor: "Competition has been both God and devil in Western civilizations. It

\footnotetext{
41 Amato (1997), op. cit., p. 112.

42 Amato (1997), op. cit., pp. 113-114.

43 Amato (1997), op. cit., p. 120.

44 Karagiannis, Yanis. "The Causes and Consequences of the Collegial Implementation of European Competition Law." European Law Journal 19.5 (2013), pp. 682-704, p. 691.

45 Karagiannis, op. cit., p. 691.

46 Karagiannis, op. cit., p. 693.

47 Karagiannis, op. cit., p. 693.
} 
has promised and provided wealth and economic progress; it has also altered the distribution of wealth, undermined communities and challenged moral codes" ${ }^{48}$ Gerber offers a comprehensive picture of the history of competition law and policy in Europe and traces many of its current features to early nineteenth century Austria.

Gerber notes that the idea of specialness of EU competition law explains why the traditional legal mechanisms have been considered inappropriate, while non-traditional methods and procedures have been embraced in the field of competition law. ${ }^{49}$

The non-traditional method that Gerber describes is the administrative control model of competition law - a constellation of ideas from the 1920 s that were imported into the fabric of competition laws adopted by various Western countries and, later, by the European Union. Gerber writes that

the pervasiveness of this orthodoxy is a key to understanding the competition law dynamics of the period and to interpreting later developments on both the national and regional levels. Yet, it is precisely this element of European experience that has been obscured by the failure to employ a Europe-wide lens in considering national competition law systems. ${ }^{50}$

Administrative control is an idea structured around the fact that government officials are authorized to take measures against powerful firms when their actions on the market were seen as harmful. The primary decision-makers in this type of system are administrators, whose decisions are often subject to review. The enforcement of such systems tends to be rather soft: "the guiding notion is that administrators should not interfere too much with business conduct. They are supposed to use publicity and pressure as the primary or exclusive means of achieving compliance".51

Gerber notes that the administrative model accommodates well many of the features of competition law: vague norms, high levels of discretion, and avoidance of criminalizing behaviours. It is also a system that has very clear advantages both for politicians and administrators. First, it allows administrators to directly influence the behaviour of large corporations rather than passing exhaustive pieces of legislation and leaving it to the courts to implement them. Second, those who manage competition laws can reap political gains by

$\begin{array}{ll}48 & \text { Gerber, op. cit., p. } 1 . \\ 49 & \text { Gerber, op. cit., p. } 12 . \\ 50 & \text { Gerber, op. cit., p. } 173 . \\ 5^{1} & \text { Gerber, op. cit., p. } 175 .\end{array}$


going after the big businesses. Such systems can be operated with little cost and with few risks. Last, the opacity of the system makes it difficult for journalists - and therefore for the public - to assess companies' behaviours or the actions taken by administrators. In fact, "businesses may find such a system a useful 'cover': it tells the public that economically powerful firms are subject to controls, but it can be operated in such a way that the controls have little bearing on business conduct". ${ }^{2}$

Some authors have seen, in the special and privileged nature of competition law, the sign of a malefic presence for society. Pirovano proposed that the 'competition order' was a "totalitarian cultural phenomenon".53 In the same vein, Boy has suggested that the competition order creates risks of domination and violence..$^{54}$ Catherine Prieto noted that the explanation for such views lies in the perception that European competition law is the highway for ultraliberalism, "a faithless, lawless, purely liberal instrument". ${ }^{55}$ She concludes that competition should have neither the caricatural nature, nor the privileged position in the hierarchy of values that is bestowed on it, but should merely be an instrument for the collective well-being. ${ }^{56}$

\subsection{Competition Policy and Fundamental Rights}

In light of the ideas discussed above, it becomes clearer why competition law and the human rights law have not yet had a deeper conversation. There might be first of all a fear of dilution. Competition law experts might fear that a more consistent approach to the fundamental rights issues arising in competition investigations would diminish their strength. Human rights law experts, on the other hand, might argue that the constant expansion of the realms that fundamental rights are called to defend can dilute the core meaning of those rights. Another question may be whether institution-building of the kind that

\footnotetext{
52 Gerber, op. cit., p. 178.

53 Pirovano, Antoine. "L'expansion de l'ordre concurrentiel dans les pays de l'Union européenne." L'Algérie en mutation: Les instruments juridiques de passage à l'économie de marché. Eds. Robert Charvin and Ammar Guesmi. Paris: L'Harmattan, 20o1, pp.129-142, p. 133 .

54 Boy, Laurence. "Lordre concurrentiel: Essai de définition d'un concept."Lordre concurrentiel: Mélanges en l'honneur d'Antoine Pirovano. Paris: Editions Frison-Roche, 2003, pp. 38-40.

55 Prieto, Catherine. "Loyauté du commerce et droit européen de la concurrence." Law and European Affairs 18.2 (2011): pp. 299-312.

56 Prieto, op. cit., p. 300.
} 
the establishment of the EU involved is actually compatible with a parallel development of human rights.

There have been an increasing number of attempts to bridge the two fields in recent years. A telling example is offered by the work of Racine who argues that the relationship between competition law and human rights is in fact much deeper than is normally accepted. More precisely, competition could not exist or develop without the right to private property and freedom of speech. ${ }^{57} \mathrm{He}$ even asks whether the right to competition is not in fact a new human right. ${ }^{58}$

Except for such occasional innovative proposals, the European academic debate surrounding the topic of competition law and fundamental rights has mainly focused on due process. This debate overgrew its simplistic beginnings, but remains heavily polarized. The debate was simplistic because it pre-emptively defined the width and depth of due process in competition law proceedings by focusing on either the administrative or criminal nature of European competition law. As I will show later, this distinction is artificial.

The academic debate on the topic of competition policy and fundamental rights is polarized around two extremes: some authors argue in favour of the maintenance of the status quo justified by the sufficiency of fair trial guarantees and the need to protect the market integration process, whereas others propose that a reform of European competition law enforcement is needed.

Wills, a hearing officer with the DG COMP and one of the most quoted scholars in this field, has been an ardent supporter of the maintenance of the status quo and has continuously shown that the existing procedures fulfil the requirements of due process. In the same vein, Adreangeli concluded that in view of the far-reaching consequences of a new due process clause in competition enforcement, the right to good administration enshrined in Article 41 of the EU Charter of Fundamental Rights should be considered instead. ${ }^{59}$

On the other side of the debate, an increasing number of authors argued in favour of the reform of European competition enforcement to accommodate an enriched version of due process. Barristers involved in competition law proceedings, such as Forrester, and academics overtly raised complaints about

57 Racine, Jean-Baptiste. “L'ordre concurrentiel et les droits de l'homme." L'ordre concurrentiel: Mélanges en l'honneur d'Antoine Pirovano. Paris: Editions Frison-Roche, 2003, pp. 423-427.

58 Racine, op. cit., pp. 429-438.

59 Andreangeli, A. EU Competition Enforcement and Human Rights. Cheltenham: Edward Elgar, 2008, pp. 244-245. 
the Commission's lack of independence and the ineffectiveness of the judicial review of EU competition law. ${ }^{60}$

6o Forrester, Ian S. "Due Process in EC Competition Cases: A Distinguished Institution with Flawed Procedures." European Law Review 34.6 (2009): pp. 817-843.

Forrester, Ian S. "A Bush in Need of Pruning: The Luxuriant Growth of Light Judicial Review." European Competition Law Annual 20og: Evaluation of Evidence and its Judicial Review in Competition Cases. Eds. Claus-Dieter Ehlermann and Mel Marquis. Oxford: Hart Publishing, 2010, pp. 319-406. 